\title{
Grazing modifies inorganic and organic nitrogen uptake by coexisting plant species in alpine grassland
}

\author{
Lili Jiang ${ }^{1}$ - Shiping Wang ${ }^{1,2} \cdot$ Zhe Pang $^{4} \cdot$ Changshun Wang $^{1} \cdot$ Paul Kardol $^{5}$. \\ Xiaoqi Zhou ${ }^{6}$ Yichao Rui ${ }^{7}$ Zhi chun Lan $^{8}$ - Yanfen Wang ${ }^{4}$ Xingliang $\mathrm{Xu}^{3}$
}

Received: 10 April 2015 /Revised: 24 September 2015 / Accepted: 28 September 2015 /Published online: 5 October 2015

(C) Springer-Verlag Berlin Heidelberg 2015

\begin{abstract}
To study how grazing affects the uptake of inorganic and organic $\mathrm{N}$ forms, three focal plant species (i.e., the graminoid species Kobresia pygmaea, which decreases with grazing, and the forbs Potentilla bifurca and Potentilla multifida, which increase with grazing) were selected in ungrazed and grazed plots in an alpine meadow on the Tibetan Plateau. Three times during the growing season (i.e., June, July, and September), these plots were injected with
\end{abstract}

Electronic supplementary material The online version of this article (doi:10.1007/s00374-015-1069-1) contains supplementary material, which is available to authorized users.

Lili Jiang

1ljiang@itpcas.ac.cn

1 Key Laboratory of Alpine Ecology and Biodiversity, Institute of Tibetan Plateau Research, Chinese Academy of Sciences, Beijing 100101, China

2 Center for Excellence in Tibetan Plateau Earth Science of the Chinese Academy of Sciences, Beijing 100101, China

3 Key Laboratory of Ecosystem Network Observation and Modeling, Institute of Geographic Sciences and Natural Resources Research, Chinese Academy of Sciences, Beijing 100101, China

4 College of Life Sciences, University of the Chinese Academy of Sciences, Beijing 100049, China

5 Department of Forest Ecology and Management, Swedish University of Agricultural Sciences, 90183 Umeå, Sweden

6 Environmental Futures Research Institute, Griffith University, Nathan, Brisbane 4111, Australia

7 Soil Biology and Molecular Ecology Lab, School of Earth and Environment, The University of Western Australia, Crawley, WA 6009, Australia

8 Center for Watershed Ecology, Institute of Life Sciences, Nanchang University, Nanchang 330031, China
${ }^{15} \mathrm{~N}$-labeled $\mathrm{NO}_{3}{ }^{-}-\mathrm{N}, \mathrm{NH}_{4}{ }^{+}-\mathrm{N}$, or glycine- $\mathrm{N}$, or with only water as a control. Two hours after ${ }^{15} \mathrm{~N}$ injection, exchangeable $\mathrm{NH}_{4}{ }^{+}-\mathrm{N}$, glycine- $\mathrm{N}$, and $\mathrm{NO}_{3}{ }^{-}-\mathrm{N}$ as well as plant and soil samples were collected and analyzed for ${ }^{15} \mathrm{~N} /{ }^{14} \mathrm{~N}$ and total $\mathrm{N}$ content. Our result showed that all three plant species took up glycine-N, but uptake of inorganic $\mathrm{N}$ was generally predominant. The graminoid $K$. pygmaea took up all three $\mathrm{N}$ forms equally in June but preferred $\mathrm{NO}_{3}{ }^{-}-\mathrm{N}$ in July (particularly under grazing) and exchangeable $\mathrm{NH}_{4}{ }^{+}-\mathrm{N}$ in September. The forbs $P$. bifurca and P. multifida preferentially took up exchangeable $\mathrm{NH}_{4}{ }^{+}-\mathrm{N}$ in July (particularly under grazing), while $\mathrm{NO}_{3}{ }^{-} \mathrm{N}$ was the dominant form of $\mathrm{N}$ uptake in September. P. bifurca generally preferred exchangeable $\mathrm{NH}_{4}{ }^{+} \mathrm{-N}$, but preference shifted toward $\mathrm{NO}_{3}{ }^{-} \mathrm{N}$ under grazing in June. P. multifida preferred glycine-N in ungrazed plots and shifted its preference to $\mathrm{NO}_{3}{ }^{-}-\mathrm{N}$ under grazing in June. In conclusion, the three plant species showed niche partitioning for uptake of three forms of $\mathrm{N}$ across the season, which was modified by grazing. These findings indicate that plant $\mathrm{N}$ uptake patterns should be considered for better understanding the mechanisms of grazing effects on plant diversity and species coexistence.

Keywords Organic N · Inorganic N · Alpine meadow · Grazing · Community succession · Plant species coexistence · Tibetan Plateau

\section{Introduction}

Livestock grazing is an important type of management practice in grasslands, which can profoundly affect soil properties and plant performance (Klein et al. 2007; Zheng et al. 2011) (Fig. 1). In low-productive ecosystems, grazing causes decreases in soil organic $\mathrm{C}$ and $\mathrm{N}$ pools (Holst et al. 2007; Hafner et al. 2012; Chen et al. 2013) and soil $\mathrm{N}$ mineralization 
Fig. 1 Schematic diagram showing effects of grazing on the plant-soil system, and potential shifts in soil ecosystem processes in alpine meadow

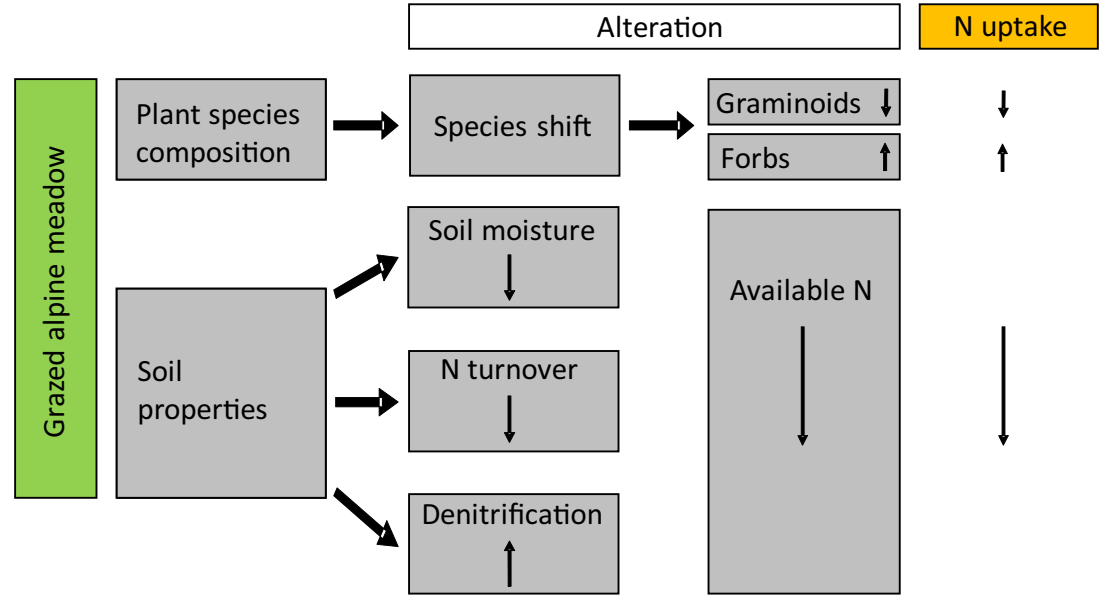

rates (Harrison and Bardgett 2004; Holst et al. 2007; Rui et al. 2011). Moreover, grazing causes shifts in plant community composition and diversity (Mcnaughton 1986; Olofsson et al. 2001; Wang et al. 2012; Yan et al. 2013). For alpine meadow, it has been shown that grazing alters plantcompetitive interactions, decreasing the cover of graminoids and increasing the cover of forbs (Wang et al. 2012). However, we are lacking understanding of how differences in plant $\mathrm{N}$ utilization strategies could drive shifts in plant community composition with shifting $\mathrm{N}$ availability under grazing. Such knowledge is needed to better predict plant community dynamics and adapt management strategies for degraded grasslands.

In most natural grasslands, plant productivity is limited by soil N availability (Vitousek and Howarth 1991; LeBauer and Treseder 2008). Plant-available N includes both organic (e.g., peptides and free amino acids) and inorganic forms (i.e., $\mathrm{NH}_{4}^{+}$and $\mathrm{NO}_{3}{ }^{-}$) (Chapin et al. 1993; Averill and Finzi 2011; Månsson et al. 2014). Increasing numbers of studies have shown that organic $\mathrm{N}$ can be an important $\mathrm{N}$ source for plants (Jones et al. 2005; Näsholm et al. 2009; Warren 2014), especially in cold terrestrial ecosystems such as arctic and alpine ecosystems due to slow $\mathrm{N}$ mineralization rates (Jones et al. 2004; Schimel and Bennett 2004; Xu et al. 2006). Individual plant species differ in the forms of $\mathrm{N}$ they take up (i.e., niche partitioning), and $\mathrm{N}$ niche partitioning has been shown to vary with $\mathrm{N}$ availability (McKane et al. 2002; Xu et al. 2011b; Gao et al. 2014). Such niche differentiation of utilized $\mathrm{N}$ forms has been suggested as an important mechanism for species coexistence in terrestrial ecosystems (McKane et al. 2002; Ashton et al. 2010; $\mathrm{Xu}$ et al. 2011a; Andersen and Turner 2013). Importantly, in unproductive grasslands, grazing not only decreases soil $\mathrm{N}$ availability but also influences soil $\mathrm{N}$ forms via feces and urine inputs (for example, increase in soil $\mathrm{NO}_{3}{ }^{-} \mathrm{N}$ concentration) (Rui et al. 2011; Wang et al. 2012).
The soil $\mathrm{N}$ resources available to plants in grassland ecosystems vary with the season (Eviner and Firestone 2007; Harrison et al. 2008; Britto and Kronzucker 2013), because plants acquire more $\mathrm{N}$ for growth early than late in the growing season (Jaeger et al. 1999; Miller et al. 2009; Xu et al. 2011a; Kuzyakov and Xu 2013). Importantly, seasonal patterns of $\mathrm{N}$ uptake may differ among plant species. For example, Gao et al. (2014) found that in an alpine wetland, Carex muliensis and Carex lasiocarpa, two early flowering species, showed higher $\mathrm{N}$ uptake rates early in the season probably because of high $\mathrm{N}$ demands for growth and reproduction. By comparison, Potentilla anserina, a rosette herb, which flowers later in the season, showed an opposite pattern. However, it remains unknown whether plant species in alpine meadows can shift their preference for $\mathrm{N}$ forms over the growing season, and how preference patterns vary among coexisting graminoids and forbs.

On the Tibetan Plateau, approximately $35 \%$ of the total land area (2.5 million $\mathrm{km}^{2}$ ) consists of alpine meadow (Piao et al. 2006; Shen et al. 2011). Livestock grazing is the main land use type in these alpine meadows, and grazing pressure is expected to substantially increase in the future (Wiener et al. 2003). Better understanding of the effects of grazing on inorganic and organic $\mathrm{N}$ uptake by dominant plant species can improve our predictive capability of shifts in species composition caused by grazing. Here, we used a shortterm ${ }^{15} \mathrm{~N}$ tracer experiment under field conditions to test the hypotheses that (1) grazing decreases $\mathrm{N}$ uptake by graminoids and increases $\mathrm{N}$ uptake by forbs, (2) $\mathrm{N}$ utilization strategies are plant species specific and shift under grazing, and (3) coexisting plants species shift their preference for $\mathrm{N}$ forms during the growing season, and seasonal patterns of $\mathrm{N}$ uptake shift under grazing because grazing can change soil $\mathrm{N}$ availability during the growing season on the Tibetan Plateau (Xu et al. 2011b). 


\section{Materials and methods}

\section{Study site and target species}

The study was conducted in an alpine meadow in Nagqu county, located in the Nagqu river basin between Tangula Mountains and Nyainqentanglha Range, Tibet $\left(30^{\circ} 31^{\prime}\right.$ to $31^{\circ} 55^{\prime} \mathrm{N}, 91^{\circ} 12^{\prime}$ to $93^{\circ} 02^{\prime} \mathrm{E}, 4450 \mathrm{~m}$ above sea level). The location is in the eastern part of Qiangtang Plateau, upstream the Nujiang river basin. The experimental site has a typical alpine climate. The average annual temperature is $-2.1{ }^{\circ} \mathrm{C}$, and the average temperature in January is $-14.4^{\circ} \mathrm{C}$. Large diurnal temperature fluctuations are common. There is no absolute frost-free period. The growing season is short, usually lasting from June to August. Mean annual precipitation is $406 \mathrm{~mm}$, most of which falls from July to September. Mean annual evaporation is $1810 \mathrm{~mm}$, and the mean relative humidity is $51 \%$ (Shen et al. 2011). The meadow vegetation is dominated by the perennial species Kobresia pygmaea, Potentilla multifida, and Potentilla bifurca and is generally known as "Kobresia pygmaea meadow." There are on average five or six plant species within a $30 \mathrm{~cm} \times 30 \mathrm{~cm}$ area. The alpine meadow soil is rich in organic $\mathrm{C}$.

\section{Experimental design}

Our experiment consisted of five blocks of ungrazed and grazed plots $(15 \mathrm{~m} \times 15 \mathrm{~m})$ (Supplementary Fig. S1). Ungrazed plots were enclosed in 2005; a field survey learned that initial vegetation cover and species composition were uniform across all ungrazed and grazed plots. Grazed plots were grazed with sheep all year round, at a density of approximately 0.36 sheep per hectare, i.e., a moderate intensity grazing (Wang et al. 2005). We selected three common plant species, i.e., K. pygmaea, a shallow-rooted, early flowering graminoid (Cyperaceae) (Dorji et al. 2013) (accounting for more than $70 \%$ of total aboveground biomass at the ungrazed and for more than $50 \%$ of the total aboveground biomass at the grazed plots), and the forbs $P$. multifida and $P$. bifurca (accounting for about $2 \%$ of total aboveground biomass at both the ungrazed and grazed plots), as the focal species of our study since these three species account for $>50 \%$ of the total aboveground biomass at both the ungrazed and grazed plots.

In June 2013, four subplots of $10 \mathrm{~cm} \times 10 \mathrm{~cm}$ were established in each of the ungrazed and grazed plots, totaling to 40 subplots (Supplementary Fig. S1). All three focal species were present in each subplot, and the distance between adjacent subplots was no less than $2 \mathrm{~m}$. Each of the four subplots was injected with water (no ${ }^{15} \mathrm{~N}$ addition) as the control or with $\mathrm{NH}_{4}{ }^{+}{ }^{15} \mathrm{~N}(99.2 \%), \mathrm{NO}_{3}{ }^{-}{ }^{15} \mathrm{~N}(99.2 \%)$, or glycine- ${ }^{15} \mathrm{~N}(98.7 \%)$. Glycine has become the model compound in many studies of plant organic $\mathrm{N}$ uptake (e.g., Schmidt and Stewart 1999; Näsholm et al. 2009). Injections were applied on 27 June (early growing season), 20 July (fast growing season), and 5 September (late growing season) in 2013. The concentration of ${ }^{15} \mathrm{~N}$ was adjusted to $90 \mathrm{mg} \mathrm{N} \mathrm{L}^{-1}$ for each of the three solutions. Each subplot was divided into nine $3 \mathrm{~cm} \times 3 \mathrm{~cm}$ squares for a homogeneous distribution of the $\mathrm{N}$ solution, and $1 \mathrm{~mL} \mathrm{~N}$ solution (or water for the control plots) was injected at $0-8-\mathrm{cm}$ soil depth, equaling to $7.5 \mu \mathrm{g} \mathrm{N} \mathrm{g}^{-1}$ soil (Xu et al. 2011a, b).

\section{Sampling and isotope analysis}

Two hours after ${ }^{15} \mathrm{~N}$ tracer injection, aboveground plant parts for each of the three species per plot were collected using scissors. Bulk soil samples were collected to a depth of 0 $10 \mathrm{~cm}$. The soil samples were immediately transported to the laboratory where it was stored at $4{ }^{\circ} \mathrm{C}$ until further processing. Fresh soil samples were analyzed for exchangeable $\mathrm{NH}_{4}{ }^{+} \mathrm{N}$ and $\mathrm{NO}_{3}{ }^{-}-\mathrm{N}$ concentration, and microbial biomass $\mathrm{N}$. Subsamples were air-dried and used for measurements of soil organic carbon (SOC), total N, glycine concentration, $\mathrm{pH}$, and bulk density. Soil glycine concentrations were determined by high-performance liquid chromatography (Waters 515) on the same extracts (Nasholm et al. 1987; Xu et al. 2011a). Soil pH was measured from a soil/water ratio of 1:2.5. SOC was analyzed using a $\mathrm{H}_{2} \mathrm{SO}_{4}-\mathrm{K}_{2} \mathrm{Cr}_{2} \mathrm{O}_{7}$ oxidation method (Nelson and Sommers 1982). Soil total $\mathrm{N}$ was analyzed using the Kjeldahl digestion method. Soil exchangeable $\mathrm{NH}_{4}{ }^{+}-\mathrm{N}$ and $\mathrm{NO}_{3}{ }^{-} \mathrm{N}$ was extracted with $2 \mathrm{M} \mathrm{KCl}$. Soil microbial biomass $\mathrm{N}$ was measured as the difference between extractable $\mathrm{N}$ concentrations in chloroform-fumigated and non-fumigated samples using a conversion factor $\left(k_{\mathrm{EN}}\right)$ of 0.45 (Lovell et al. 1995). All results were expressed on an oven-dried soil basis.

Plant roots were carefully removed from soils and rinsed first with tap water to clean off attached soil and then immersed in $0.5 \mathrm{mmol} \mathrm{L}^{-1} \mathrm{CaCl}_{2}$ solutions for $30 \mathrm{~min}$ and rinsed with distilled water to remove tracers absorbed to the root surface. Shoots and roots were then dried at $70{ }^{\circ} \mathrm{C}$ for $48 \mathrm{~h}$ and weighed for biomass. Then, shoot and root material was ground to a fine powder using a ball mill (MM2, Fa. Retsch, Haan, Germany) and into tin capsules for analysis of total $\mathrm{N}$ and ${ }^{15} \mathrm{~N} /{ }^{14} \mathrm{~N}$ ratios by continuous-flow gas isotope ratio mass spectrometry (MAT253, Finnigan MAT, Bremen, Germany), coupled by a ConFlo III device (Finnigan MAT, Bremen, Germany) to an elemental analyzer (EA 1112, CE Instruments, Milan, Italy).

\section{Calculations}

For each plant species, APE (the atom $\%$ excess) was calculated as follows:

$A P E={ }^{15} N_{\text {added }}-{ }^{15} N_{\text {control }}$ 
where the ${ }^{15} N_{\text {added }}$ is the ${ }^{15} \mathrm{~N}$ added to plots and ${ }^{15} N_{\text {control }}$ is the mean ${ }^{15} \mathrm{~N}$ of the respective control plots.

The $\mathrm{N}$ uptake rate $\left(\mu \mathrm{g} \mathrm{N} \mathrm{g}^{-1}\right.$ dry weight root $\left.\mathrm{h}^{-1}\right)$, as a representation of plant $\mathrm{N}$ acquisition ability (McKane et al. 2002), was calculated as follows:

$$
\begin{aligned}
N \text { uptake rate }= & \text { plant } N \text { content }\left(\mu \mathrm{g} \mathrm{N} \mathrm{g}^{-1} \mathrm{dry} \text { weight soil }\right) \\
& \times A P E \times \text { total plant biomass }\left(\mathrm{g} \mathrm{m}^{-2}\right) \\
& / \text { plant root mass }\left(\mathrm{g} \mathrm{m}^{-2}\right) / \text { time }(\mathrm{h}) \\
& /\left(m_{\text {unlabelled }} / m_{\text {labelled }}\right)
\end{aligned}
$$

where $m_{\text {labelled }}$ is the total mass $\left(\mathrm{g} \mathrm{m}^{-2}\right)$ of ${ }^{15} \mathrm{~N}$ for each $\mathrm{N}$ form injected per plot, and $m_{\text {unlabelled }}$ is the mass of the corresponding $\mathrm{N}$ form already present in soil (Xu et al. 2011b). Plant relative biomass (\%) was calculated as plant species biomass divided by the total plant community biomass. Plant N stock was calculated as plant biomass $\left(\mathrm{g} \mathrm{m}^{-2}\right)$ multiplied by plant $\mathrm{N}$ concentration (\%). The percentage of different $\mathrm{N}$ forms was calculated by dividing the uptake of individual forms of $\mathrm{N}$ $\left(\mathrm{NH}_{4}{ }^{+}-\mathrm{N}, \mathrm{NO}_{3}{ }^{-} \mathrm{N}\right.$, or glycine-N) by total plant $\mathrm{N}$ uptake (Xu et al. 2011a).

\section{Data analysis}

Plant and soil properties were analyzed using two-way analysis of variance (ANOVA) with grazing (ungrazed, grazed) and plant species (K. pygmaea, P. bifurca, $P$. multifida) or grazing and season (June, July, September) as fixed factors. When significant grazing effects were observed, independent $t$ tests were used to test for differences between ungrazed and grazed treatments. Treatment effects on $\mathrm{N}$ uptake rate were tested using linear mixed models with plant species (K. pygmaea, P. bifurca, P. multifida), $\mathrm{N}$ form $\left(\mathrm{NH}_{4}{ }^{+}-\mathrm{N}, \mathrm{NO}_{3}{ }^{-} \mathrm{N}\right.$, and glycine-N), grazing (ungrazed, grazed) as fixed factors, and season (June, July, and September) as repeated measure (Jiang et al. 2011; Yang et al. 2011). Block was included as random factor. Effects of block were not significant and, hence, were not further considered. Duncan's new multiple range test (MRT) was used for post hoc comparisons. One-way ANOVA followed by Duncan's MRT was used to examine the differences in biomass and root-to-shoot ratios among the three focal species. To determine those factors that best explained variation in plant biomass, we used stepwise multiple regressions, including mean SOC, soil total $\mathrm{N}$, soil exchangeable $\mathrm{NH}_{4}{ }^{+}-\mathrm{N}, \mathrm{NO}_{3}{ }^{-}-\mathrm{N}$, glycine concentration, soil moisture, and soil $\mathrm{pH}$. For ANOVAs, normality was checked with $\mathrm{K}-\mathrm{S}$ tests, and the assumptions of homogeneity of variances were checked using Levene's test. If the assumptions were not met, data were log-transformed prior to analysis. The analyses were conducted using SPSS 18.0
(SPSS Inc., Chicago, IL, USA). All significances were considered at $P<0.05$ level.

\section{Results}

\section{The effects of grazing and season on plant biomass and $\mathrm{N}$ stock}

In contrast to ungrazing, grazing significantly affected plant species biomass and their relative biomass in the community, plant root-to-shoot ratio, and plant $\mathrm{N}$ stock. However, effects varied with season and differed among plant species (Supplementary Table S1). Grazing significantly decreased K. pygmaea biomass (Fig. 2a), its relative biomass in July and September (Fig. 2b), and its $\mathrm{N}$ stock (Fig. 2c), whereas grazing increased the root-toshoot ratio of $K$. pygmaea (Fig. 2d). Grazing also significantly decreased P. multifida biomass (Fig. 2a) and $\mathrm{N}$ stock (Fig. 2c) but increased its relative biomass in September (Fig. 2b) and its root-to-shoot ratio (Fig. 2d). Grazing did not affect P. bifurca biomass (Fig. 2a) but increased its relative biomass in June and September (Fig. 2b), $\mathrm{N}$ stock in July (Fig. 2c), and its root-toshoot ratio in June and September (Fig. 2d).

\section{The effects of grazing and season on soil properties}

In contrast to ungrazing, grazing significantly increased soil bulk density (Fig. 3b) but decreased SOC (Fig. 3c), soil total N (Fig. 3d), soil microbial biomass $\mathrm{N}$ (Fig. 3f), $\mathrm{NO}_{3}^{-}{ }^{-} \mathrm{N}$ (Fig. 3h), glycine (Fig. 3i) concentration, and soil $\mathrm{C} / \mathrm{N}$ ratio (Fig. 3e). Grazing did not affect soil pH (Fig. 3a). Grazing significantly decreased soil exchangeable $\mathrm{NH}_{4}^{+}-\mathrm{N}$ concentration, but only in June (Fig. 3g). SOC, soil total N, and soil exchangeable $\mathrm{NH}_{4}{ }^{+}-\mathrm{N}$ were higher in July and September than in June, while glycine concentration was higher in September than in June (Fig. 3i).

\section{The effect of grazing on plant uptake rates of different $\mathbf{N}$ forms}

Total $\mathrm{N}$ uptake rates (including exchangeable $\mathrm{NH}_{4}{ }^{+}-\mathrm{N}$, $\mathrm{NO}_{3}{ }^{-}-\mathrm{N}$, and glycine-N) differed among plant species $(F=$ 9.83, $P<0.001)$ and seasons $(F=21.89, P<0.001)$. Uptake rates were lowest for $K$. pygmaea: Values were up to three times higher in P. bifurca and P. multifida (Fig. 4a). Total N uptake rates were lowest in June and highest in September (Fig. 4b). Further, there were significant two-way interactions of species $\times$ seasons and season $\times$ grazing $(P<0.001)$. In June, the total $\mathrm{N}$ uptake rate was almost three times higher for $K$. pygmaea and $P$. multifida than for $P$. bifurca, while values were higher for $P$. multifida and $P$. bifurca than for K. pygmaea 


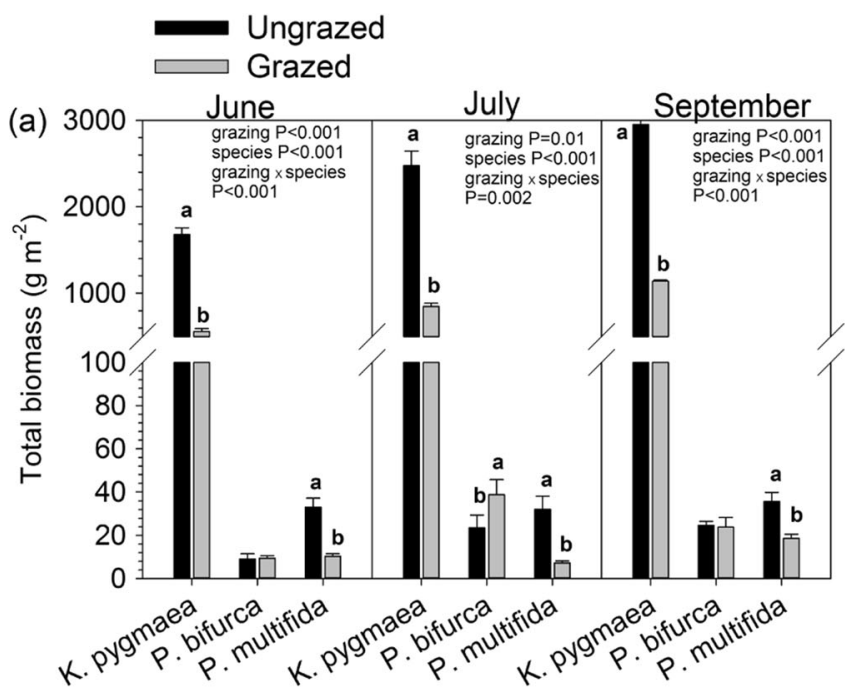

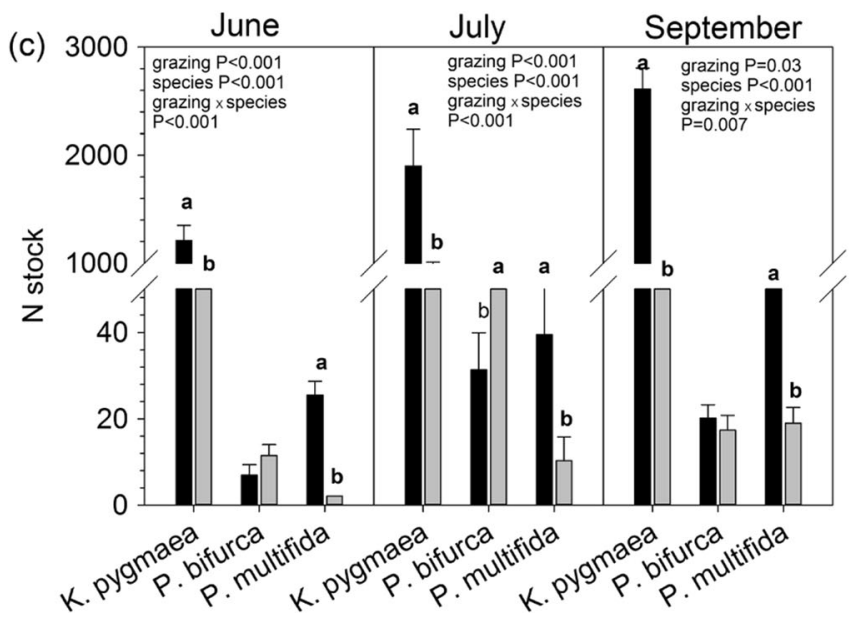

Fig 2 Effects of grazing and season on plant species biomass $\left(\mathrm{g} \mathrm{m}^{-2}\right)$, relative biomass (\%), plant $\mathrm{N}$ stock $\left(\mathrm{g} \mathrm{m}^{-2}\right)$, and plant root/shoot ratio in alpine meadow on the Qinghai-Tibetan plateau. Values are means $\pm \mathrm{SE}$

in July and September (Fig. 4c). In contrast to ungrazing, grazing decreased total $\mathrm{N}$ uptake, but only in September (Fig. 4d).

Uptake rates of different $\mathrm{N}$ forms were significantly affected by plant species, season, and $\mathrm{N}$ form (Fig. $4 \mathrm{e}-$ $\mathrm{g})$, and the interactions between grazing and/or plant species and/or season and/or $\mathrm{N}$ form (Fig. 5). Generally, $\mathrm{N}$ uptake rates were the lowest in K. pygmaea (Fig. 4e), highest in July (Fig. 4f), and higher for exchangeable $\mathrm{NH}_{4}{ }^{+}-\mathrm{N}$ and $\mathrm{NO}_{3}{ }^{-}-\mathrm{N}$ than for glycine (Fig. 4g). For $K$. pygmaea, in contrast to ungrazing, grazing significantly decreased exchangeable $\mathrm{NH}_{4}{ }^{+}-\mathrm{N}, \mathrm{NO}_{3}{ }^{-}-\mathrm{N}$, and glycine- $\mathrm{N}$ uptake rates in September (Fig. $5 \mathrm{~g}$ ), while for P. bifurca, grazing increased $\mathrm{NO}_{3}{ }^{-} \mathrm{N}$ uptake rates in June and July and decreased exchangeable $\mathrm{NH}_{4}{ }^{+}-\mathrm{N}$ uptake rates in July (Fig. 5e). For P. multifida, grazing significantly increased exchangeable $\mathrm{NH}_{4}{ }^{+}-\mathrm{N}$ and $\mathrm{NO}_{3}{ }^{-}-\mathrm{N}$ uptake rates in June but decreased exchangeable $\mathrm{NH}_{4}{ }^{+}-\mathrm{N}$ and $\mathrm{NO}_{3}{ }^{-} \mathrm{N}$ uptake
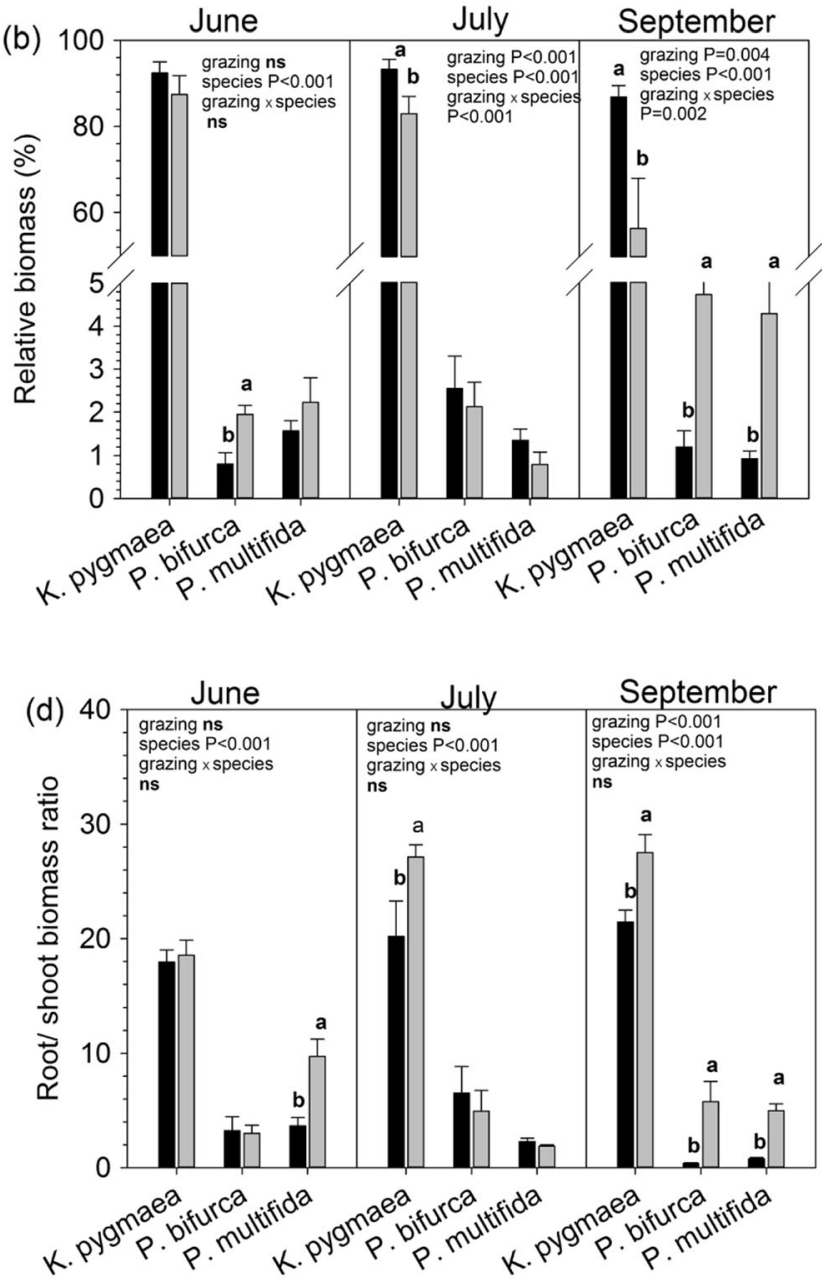

$(n=5)$. The $P$ values in the panels were derived from two-way ANOVA. Letters above bars indicate significant difference between ungrazed and grazed plots

rates in September and decreased glycine-N uptake rates in June, July, and September (Fig. 5c, f, i).

\section{Discussion}

Grazing significantly decreased $\mathrm{N}$ uptake by the graminoid (K. pygmaea) but did not affect $\mathrm{N}$ uptake by the forbs (P. bifurca and P. multifidi). Although the number of species we used was small, this provides some support for our first hypothesis that grazing decreases $\mathrm{N}$ uptake by graminoids and increases $\mathrm{N}$ uptake by forbs. A possible explanation is that sheep prefer K. pygmaea relative to the two forbs. Grazing decreased plant biomass of $K$. pygmaea and thus its $\mathrm{N}$ uptake which can be ascribed to selective grazing (Dorji et al. 2013). Additionally, our findings indicated that significant season $\times$ species $\times \mathrm{N}$ form $\times$ grazing interactions can offset the effects of grazing on $\mathrm{N}$ uptake by forbs, e.g., grazing demonstrated 

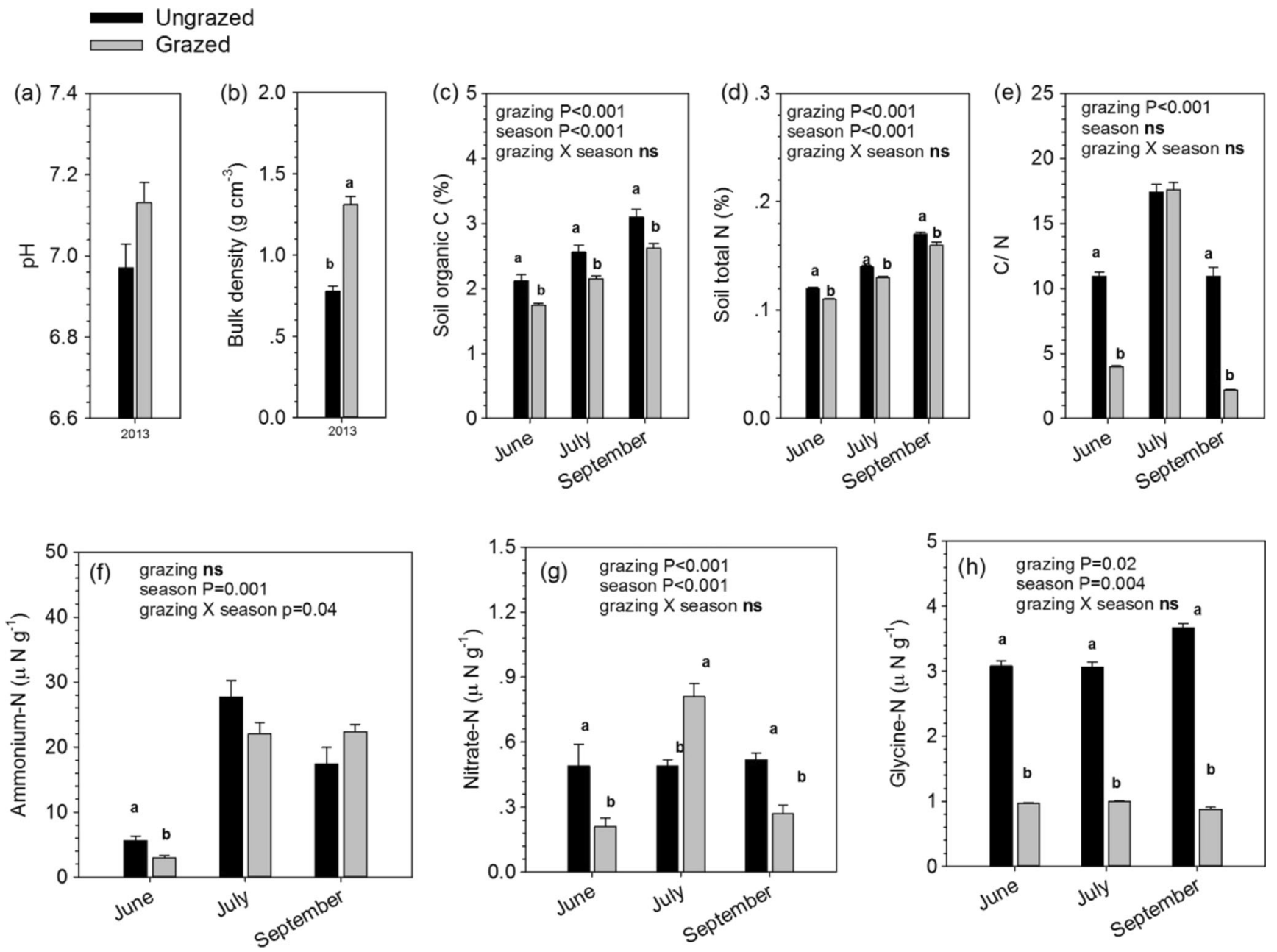

Fig. 3 Effects of grazing and season on soil properties $(0-10 \mathrm{~cm})$ in alpine meadow on the Qinghai-Tibetan plateau. Values are means \pm SE $(n=5)$. The $P$ values in the panels were derived from two-way ANOVA. Letters above bars indicate significant difference between ungrazed and grazed plots

opposite effects for $\mathrm{NO}_{3}{ }^{-}$and $\mathrm{NH}_{4}{ }^{+}$uptake by P. bifurca (Fig. 5c, e and Supplementary Table S2).

We observed that effects of grazing on plant $\mathrm{N}$ uptake may depend on plant species and $\mathrm{N}$ form. This supports our second hypothesis. K. pygmaea showed the lowest plant $\mathrm{N}$ uptake rate, which is consistent with its relatively slow growth rate (Dorji et al. 2013). The faster growing species $P$. bifurca and P. multifida showed higher plant $\mathrm{N}$ uptake rates. We do not know the underlying mechanisms, but this difference might be linked to trait differences among these plant species. P. bifurca and $P$. multifida had lower root biomass and a greater shoot-toroot ratio compared to K. pygmaea (Fig. 2d). It has been shown that plants with higher root biomass can increase root exudation and favor rhizosphere microorganisms with faster turnover and shorter generation times, leading to decreased plant $\mathrm{N}$ uptake rates (Blagodatskaya et al. 2014). Moreover, plant with different $\mathrm{N}$ use efficiencies (NUEs) can affect activity, composition, and biomass of microbial communities of rhizosphere soils. These changes can also have effects on plant $\mathrm{N}$ uptake (Pathan et al. 2015a; Pathan et al. 2015b). Taken together, this indicates overall higher $\mathrm{N}$ acquisition and $\mathrm{NUE}$ for P. bifurca and P. multifida than for K. pygmaea.

Our results showed that inorganic $\mathrm{N}$ generally was the prevailing $\mathrm{N}$ form utilized by plants in the $K$. pygmaea meadow regardless of grazing but, importantly, also that plant preference for different $\mathrm{N}$ forms was strongly species specific (Supplementary Fig.S3b). For the slow-growing species $K$. pygmaea, $\mathrm{N}$ uptake rates were similar for the three $\mathrm{N}$ forms. In contrast, $P$. multifida, a faster-growing species with lower biomass accumulation, showed a preference for exchangeable $\mathrm{NH}_{4}{ }^{+}-\mathrm{N}$ and $\mathrm{NO}_{3}{ }^{-}-\mathrm{N}$ over glycine-N. This suggests that in our alpine meadow, plant species with high biomass and low growth rate may use more organic $\mathrm{N}$ than low-productive and fastgrowing species. This was supported by the finding that Kobresia humilis, a slow-growing species in K. humilis meadows, showed a greater capacity to take up organic $\mathrm{N}$ than inorganic $\mathrm{N}$ (Xu et al. 2006). The patterns observed in our study are, however, somewhat different from the patterns reported by McKane et al. (2002) who found that in an arctic tundra ecosystem, the most dominant plant species preferentially utilized the 
Fig. 4 The main effects of (a) species and (b) season, and the interactive effects of $(\mathbf{c})$ species $\times$ season, (d) season $\times$ grazing on total $\mathrm{N}$ uptake rate, and the main effects of (e) species, (f) season, (g) $\mathrm{N}$ form, and (h) grazing on mean $\mathrm{N}$ uptake rates in alpine meadow on the Qinghai-Tibetan Plateau. Values are means $\pm \mathrm{SE}$ $(n=40$ for (a), (b), (e)- (g); $n=5$ for (c); $n=20$ for (d); $n=60$ for (h)). Bars sharing the same letter are not significantly different at $P<0.05$
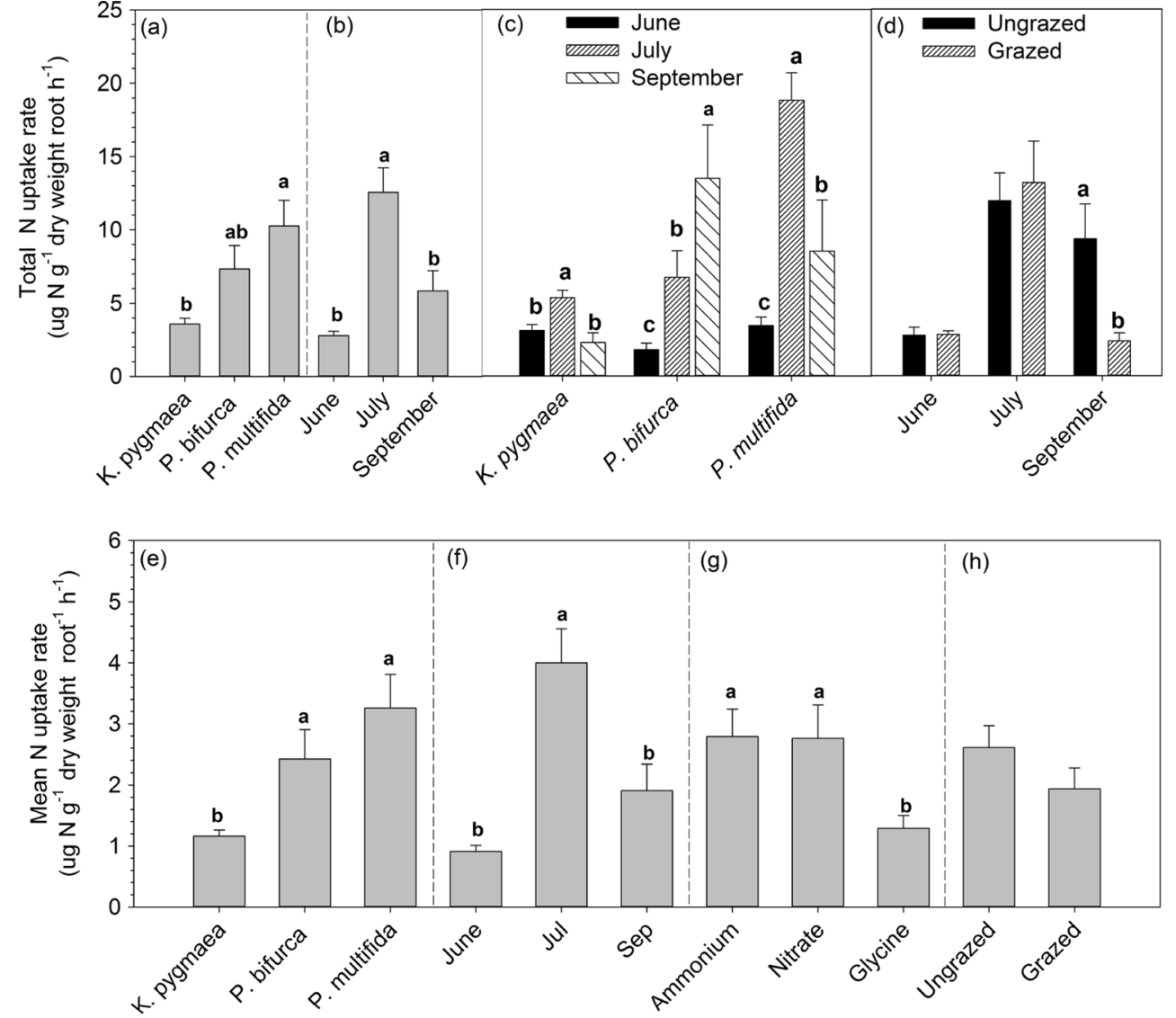

K. pygmaea

P. bifurca

P. multifida

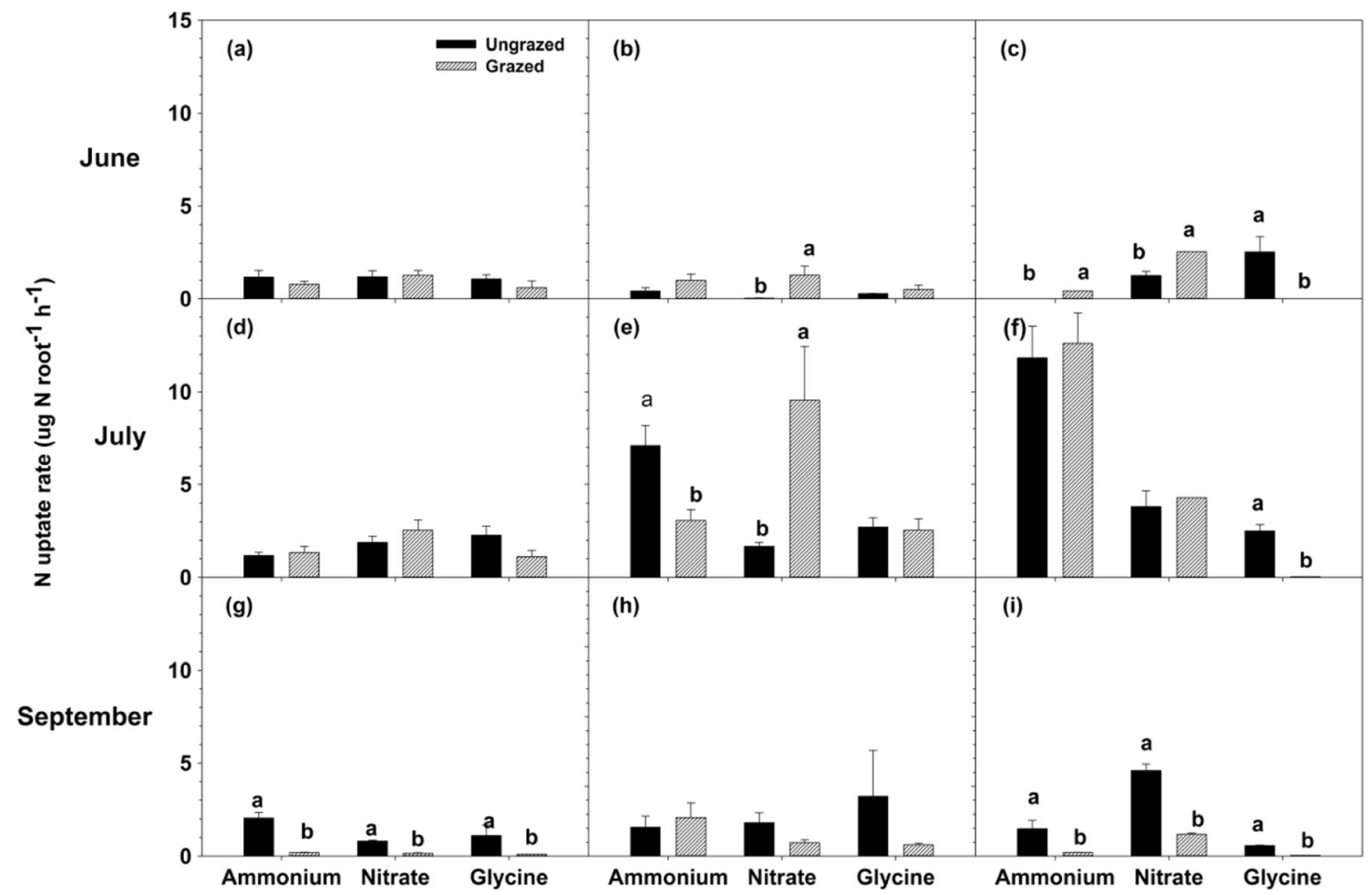

Fig. 5 The effects of plant species, $\mathrm{N}$ form, season, and grazing on ${ }^{15} \mathrm{~N}$ uptake rate of three dominant plant species in ungrazed and grazed plots in alpine meadow on the Qinghai-Tibetan Plateau. Values are means \pm SE $(n=5)$ 
most dominant $\mathrm{N}$ form, while less dominant species used less abundant $\mathrm{N}$ forms. In our ecosystem, plant growth is strongly limited by available N. Under these conditions, slow-growing, dominant species with high biomass may invest to take up different $\mathrm{N}$ forms at more or less constant rates, while the fastergrowing subdominant species may be more plastic and take up the $\mathrm{N}$ form most easily available. Although we did not examine the intrinsic mechanism responsible for $\mathrm{N}$ uptake by plants in this study, the observed patterns could be due to genes encoding proteins including those involved in $\mathrm{N}$ transport (Nacry et al. 2013). In this experiment, we did not measure glycine mineralization rates for the 2-h period between injection and sampling. However, under natural conditions, the half-life time of glycine- ${ }^{15} \mathrm{~N}$ is more than $12 \mathrm{~h}$ (Unteregelsbacher et al. 2012). As such, we consider the use of glycine- ${ }^{15} \mathrm{~N}$ appropriate for testing the uptake of organic $\mathrm{N}$ by plants. We acknowledge that dual-labeled glycine $\left({ }^{13} \mathrm{C},{ }^{15} \mathrm{~N}\right)$ could have provided additional evidence (Streeter et al. 2000; Vinolas et al. 2001; McFarland et al. 2010), but the use of dual-labeled glycine was beyond the budget of our study. Further studies are needed to establish the mechanisms of available $\mathrm{N}$ use in alpine meadow to fully assess its significance for plant nutrition in these ecosystems.

Although exchangeable $\mathrm{NH}_{4}{ }^{+}-\mathrm{N}$ was the dominant $\mathrm{N}$ form during the growing season, grazing increased $\mathrm{NO}_{3}{ }^{-} \mathrm{N}$ uptake by $P$. bifurca in June and July and decreased exchangeable $\mathrm{NH}_{4}{ }^{+}-\mathrm{N}$ uptake in July. This could be related to the concentrations of $\mathrm{NO}_{3}{ }^{-}-\mathrm{N}$ and exchangeable $\mathrm{NH}_{4}{ }^{+}-\mathrm{N}$ in the soil solution. Grazing increased $\mathrm{NO}_{3}{ }^{-}-\mathrm{N}$ concentrations in June and July, which resulted in high $\mathrm{NO}_{3}{ }^{-}-\mathrm{N}$ uptake by $P$. bifurca, probably because $\mathrm{NO}_{3}{ }^{-}-\mathrm{N}$ uptake is induced by nitrate availability (Kudoyarova et al. 2015). Higher $\mathrm{NH}_{4}^{+}$concentrations in July resulted in an increase in $P$. bifurca $\mathrm{N}$ stock under ungrazed conditions, indicating that this species takes up the $\mathrm{N}$ form most easily available. The positive correlation between soil exchangeable $\mathrm{NH}_{4}{ }^{+} \mathrm{N}$ concentration and $\mathrm{N}$ uptake by P. bifurca (Supplementary Table S3) further supports this conclusion. This indicates that exchangeable $\mathrm{NH}_{4}{ }^{+}-\mathrm{N}$ plays an important role in $\mathrm{N}$ uptake by $P$. bifurca. Grazing significantly decreased biomass of $P$. multifida and glycine-N uptake across the season, but it did not affect $\mathrm{NO}_{3}{ }^{-}$and $\mathrm{NH}_{4}{ }^{+}$uptake (Fig. 4). Grazing increased $\mathrm{NO}_{3}{ }^{-}$and $\mathrm{NH}_{4}{ }^{+}$uptake by P. multifida in June, had no effect in July, and decreased $\mathrm{NH}_{4}{ }^{+}$uptake in September. Such divergent patterns of $\mathrm{N}$ uptake indicate that P. multifida is opportunistic and may have difficulties to persist in the plant community when grazing pressure increases $(\mathrm{Li}$ et al. 2015). Nitrogen uptake by K. pygmaea was well correlated with glycine (Supplementary Table S3), indicating that this species relies on the uptake of low molecular weight organic $\mathrm{N}$ compounds (Xu et al. 2004). However, grazing decreased glycine-N uptake by K. pygmaea, especially in September. This is supported by previous finding that grazing can significantly decrease the concentrations of glycine- $\mathrm{N}$ in the soil (Fig. 3i) and hence its uptake by this species (Xu et al. 2011a).
We found support for our third hypothesis, i.e., coexisting plants species shift their preference for $\mathrm{N}$ forms during the growing season, and seasonal patterns of $\mathrm{N}$ uptake shift under grazing. This provides partial evidence for resource partitioning across the growing season. For example, the most productive species K. pygmaea preferred $\mathrm{NO}_{3}{ }^{-} \mathrm{N}$ in July and exchangeable $\mathrm{NH}_{4}{ }^{+}$$\mathrm{N}$ in September, while the lower-productive species $P$. bifurca and $P$. multifida preferred $\mathrm{NO}_{3}{ }^{-}-\mathrm{N}$ and glycine-N in June, exchangeable $\mathrm{NH}_{4}{ }^{+}-\mathrm{N}$ in July, and $\mathrm{NO}_{3}{ }^{-} \mathrm{N}$ uptake in September. This suggests that lower-productive species in the plant community might contribute to species coexistence in $\mathrm{N}$-limited ecosystems through modulating $\mathrm{N}$ acquisition in time and $\mathrm{N}$ form (McKane et al. 2002; Miller and Bowman 2003; Harrison et al. 2008; Kuzyakov and Xu 2013).

The effects of grazing on niche partitioning depended on plant species and season. P. bifurca and P. multifida showed similar patterns switching from exchangeable $\mathrm{NH}_{4}{ }^{+}-\mathrm{N} / \mathrm{gly}-$ cine- $\mathrm{N}$ uptake in ungrazed plots to $\mathrm{NO}_{3}^{-}-\mathrm{N}$ uptake in grazed plots in June and increased exchangeable $\mathrm{NH}_{4}{ }^{+} \mathrm{N}$ utility in grazed plots in July (Fig. 5). However, grazing did not affect the $\mathrm{N}$ uptake patterns of $K$. pygmaea even though grazing significantly decreased its biomass and relatively abundance

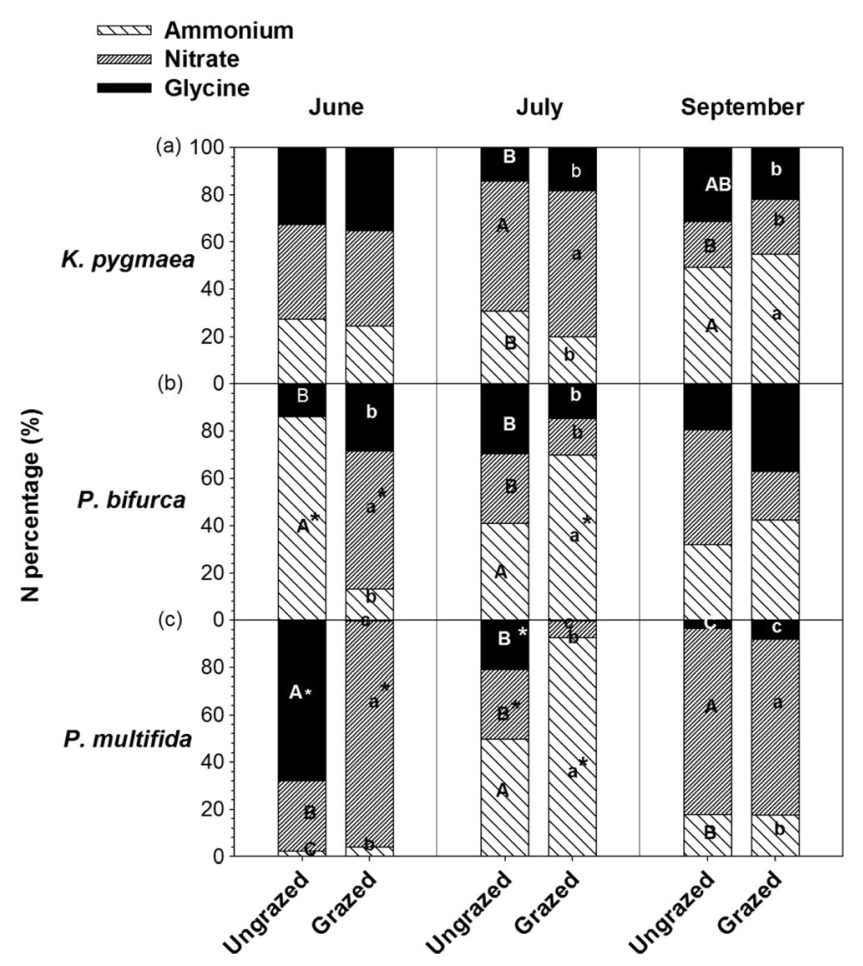

Fig. 6 Contribution of ammonium, nitrate, and glycine to total $\mathrm{N}$ uptake (as \%) for three dominant plant species in ungrazed and grazed plots in alpine meadow on the Tibetan Plateau in June, July, and September ( $n=$ 5). Within seasons, species, and grazing treatments, different letters indicate significant differences $(P<0.05)$ among the three $\mathrm{N}$ forms. Uppercase letters show the difference among the three $\mathrm{N}$ forms in ungrazed plots and lowercase letters show the difference among the three $\mathrm{N}$ forms in grazed plots. Asterisk indicates significant differences in contribution between ungrazed and grazed plots 
in the plant community (Fig. 6). Therefore, our results suggest that different plant species could develop different $\mathrm{N}$ uptake patterns under ungrazed and grazed conditions which could facilitate their coexisting in alpine meadows. A possible explanation is that $P$. bifurca and $P$. multifida predominantly acquired exchangeable $\mathrm{NH}_{4}{ }^{+}-\mathrm{N}$ and glycine- $\mathrm{N}$ in June, i.e., the least preferred $\mathrm{N}$ forms, to reduce competition with the dominant plant species K. pygmaea which is leafing and flowering earlier (Dorji et al. 2013). When competition was alleviated under grazing - as we observed in July - P. bifurca and P. multifida shifted toward using the more favorable $\mathrm{N}$ forms. Several lines of evidence indicate that some alpine meadow species preferentially utilize $\mathrm{NO}_{3}{ }^{-} \mathrm{N}$ (Miller et al. 2007; Xu et al. 2004, 2011a,b). Moreover, field observations have shown that $P$. bifurca gradually becomes dominant under conditions of overgrazing (Wang et al. 2006), which suggests that plant species preferring $\mathrm{NO}_{3}{ }^{-}-\mathrm{N}$ may increase in dominance when grazing pressure increases.

Inconsistent with previous studies (Jaeger et al. 1999; Bardgett et al. 2003), our results showed that higher plant $\mathrm{N}$ uptake was observed in the middle of the growing season (July) rather than early in the growing season (June, Fig. 4f). The meadows in our study are strongly influenced by the alpine climate with cold winters, and short, cool summers; as such, temperature during the rainy season is a main driver of plant production (Zhou 2001). Higher temperature and precipitation in July result in higher aboveground biomass production. This increases $\mathrm{N}$ requirements for alpine plants and thus plant $\mathrm{N}$ uptake. Additionally, plants may compete with soil microorganisms more strongly for $\mathrm{N}$ in July than in June because higher plant root biomass in July could make the plants strong competitors for $\mathrm{N}$ in alpine meadows (Xu et al. 2011b). Future studies should focus more on the competition between plants and soil microorganisms for $\mathrm{N}$ to further elucidate the role of soil microorganisms in modulating soil $\mathrm{N}$ partitioning. Moreover, a significant interaction of season $\times$ species $\times \mathrm{N}$ form $\times$ grazing was found. This indicated that the season pattern of plant $\mathrm{N}$ uptake was modulated by plant species, $\mathrm{N}$ forms, and grazing and was limited by the interactions.

\section{Conclusion}

Our results revealed that grazing significantly decreased the relative biomass of the graminoid K. pygmaea and increased the relative biomass of the forbs P. bifurca and P. multifida and decreased soil $\mathrm{N}$ availability. Grazing significantly decreased total $\mathrm{N}$ uptake by the graminoid but did not affect $\mathrm{N}$ uptake by the forbs. Further, our results showed that alpine plants can take up substantial amounts of organic $\mathrm{N}$, although inorganic $\mathrm{N}$ was the main $\mathrm{N}$ form utilized. The three plant species in our study showed partial niche partitioning for uptake of inorganic and organic $\mathrm{N}$ forms across the season. Moreover, grazing modified the seasonal plant partitioning for uptake of inorganic and organic N. As such, plant partitioning for N forms was affected by plant species identity, season, grazing, and their interactions. Taken together, our findings indicate that plant uptake patterns of organic and inorganic $\mathrm{N}$ should be considered for understanding the patterns of plant diversity and coexistence, and how those patterns might shift under changing environmental conditions.

Acknowledgments This work was supported by funding from the National Science Foundation of China (41230750, 41301600), the National Basic Research Program (2013CB956000), and the Strategic Priority Research Program (B) of the Chinese Academy of Sciences (XDB03030403).

\section{References}

Andersen KM, Turner BL (2013) Preferences or plasticity in nitrogen acquisition by understorey palms in a tropical montane forest. $\mathbf{J}$ Ecol 101:819-825

Ashton IW, Miller AE, Bowman WD, Suding KN (2010) Niche complementarity due to plasticity in resource use: plant partitioning of chemical N forms. Ecology 91:3252-3260

Averill C, Finzi AC (2011) Increasing plant use of organic nitrogen with elevation is reflected in nitrogen uptake rates and ecosystem delta $\mathrm{N}^{15}$. Ecology 92:883-891

Bardgett RD, Streeter TC, Bol R (2003) Soil microbes compete effectively with plants for organic-nitrogen inputs to temperate grasslands. Ecology 84:1277-1287

Blagodatskaya B, Littschwager J, Lauerer M, Kuzyakov Y (2014) Plant traits regulating $\mathrm{N}$ capture define microbial competition in the rhizosphere. Eur J Soil Biol 61:41-48

Britto DT, Kronzucker HJ (2013) Ecological significance and complexity of N-source preference in plants. Ann Bot 112:957-963

Chapin FS, Moilanen L, Kielland K (1993) Preferential use of organic nitrogen for growth by a non-mycorrhizal arctic sedge. Nature 361: $150-153$

Chen H, Zhu Q, Peng C, Wu N, Wang Y, Fang X, Gao Y, Zhu D, Yang G, Tian J, Kang X, Piao S, Ouyang H, Xiang W, Luo Z, Jiang H, Song X, Zhang YG, Zhao X, Gong P, Yao T, Wu J (2013) The impacts of climate change and human activities on biogeochemical cycles on the Qinghai-Tibetan Plateau. Glob Chang Biol 19:2940-2955

Dorji T, Totland O, Moe SR, Hopping KA, Pan JB, Klein JA (2013) Plant functional traits mediate reproductive phenology and success in response to experimental warming and snow addition in Tibet. Glob Chang Biol 19:459-472

Eviner VT, Firestone MK (2007) Mechanisms determining patterns of nutrient dynamics. In: Stromberg MR, Corbin JD, D'Antonio CM (eds) California Grasslands:ecology and management. University of California Press, California, pp 94-106

Gao JQ, Mo Y, Xu XL, Zhang XW, Yu FH (2014) Spatiotemporal variations affect uptake of inorganic and organic nitrogen by dominant plant species in an alpine wetland. Plant Soil 381:271-278

Hafner S, Unteregelsbacher S, Seeber E, Lena B, Xu X, Li X, Guggenberger G, Miehe G, Kuzyakov Y (2012) Effect of grazing on carbon stocks and assimilate partitioning in a Tibetan montane pasture revealed by ${ }^{13} \mathrm{CO}_{2}$ pulse labeling. Glob Chang Biol 18:528 538

Harrison KA, Bardgett RD (2004) Browsing by red deer negatively impacts on soil nitrogen availability in regenerating native forest. Soil Biol Biochem 36:115-126 
Harrison KA, Bol R, Bardgett RD (2008) Do plant species with different growth strategies vary in their ability to compete with soil microbes for chemical forms of nitrogen? Soil Biol Biochem 40:228-237

Holst J, Liu CY, Bruggemann N, Butterbach-Bahl K, Zheng XH, Wang YS, Han SH, Yao ZS, Yue J, Han XG (2007) Microbial N turnover and $\mathrm{N}$-oxide $\left(\mathrm{N}_{2} \mathrm{O} / \mathrm{NO} / \mathrm{NO}_{2}\right)$ fluxes in semi-arid grassland of Inner Mongolia. Ecosystems 10:623-634

Jaeger CH, Monson RK, Fisk MC, Schmidt SK (1999) Seasonal partitioning of nitrogen by plants and soil microorganisms in an alpine ecosystem. Ecology 80:1883-1891

Jiang LL, Han XG, Dong N, Wang YF, Kardol P (2011) Plant species effects on soil carbon and nitrogen dynamics in a temperate steppe of northern China. Plant Soil 346:331-347

Jones DL, Shannon D, Murphy DV, Farrar J (2004) Role of dissolved organic nitrogen $(\mathrm{DON})$ in soil $\mathrm{N}$ cycling in grassland soils. Soil Biol Biochem 36:749-756

Jones DL, Healey JR, Willett VB, Farrar JF, Hodge A (2005) Dissolved organic nitrogen uptake by plants - an important $\mathrm{N}$ uptake pathway? Soil Biol Biochem 37:413-423

Klein JA, Harte J, Zhao XQ (2007) Experimental warming, not grazing, decreases rangeland quality on the Tibetan Plateau. Ecol Appl 17: $541-557$

Kudoyarova GR, Dodd IC, Veselov DS, Rothwell SA, Veselov SY (2015) Common and specific responses to availability of mineral nutrients and water. J Exp Bot 66:2133-2144

Kuzyakov Y, Xu X (2013) Competition between roots and microorganisms for nitrogen: mechanisms and ecological relevance. New Phytol 198:656-669

LeBauer DS, Treseder KK (2008) Nitrogen limitation of net primary productivity in terrestrial ecosystems is globally distributed. Ecology 89:371-379

Li K, Liu X, Song L, Gong Y, Lu C, Yue P, Tian C, Zhang F (2015) Response of alpine grassland to elevated nitrogen deposition and water supply in China. Oecologia 177:65-72

Lovell RD, Jarvis SC, Bardgett RD (1995) Soil microbial biomass and activity in long-term grassland - effects of management changes. Soil Biol Biochem 27:969-975

Månsson KF, Olsson MO, Falkengren GU, Bengtsson G (2014) Soil moisture variations affect short-term plant-microbial competition for ammonium, glycine, and glutamate. Ecol Evol 4:1061-1072

Mcfarland JW, Ruess RW, Kielland K, Pregitzer K, Hendrick R (2010) Glycine mineralization in situ closely correlates with soil carbon availability across six North American forest ecosystems. Biogeochemistry 99:175-191

McKane RB, Johnson LC, Shaver GR, Nadelhoffer KJ, Rastetter EB, Fry B, Giblin AE, Kielland K, Kwiatkowski BL, Laundre JA (2002) Resource-based niches provide a basis for plant species diversity and dominance in arctic tundra. Nature 415:68-71

Mcnaughton SJ (1986) On Plants and Herbivores. Am Nat 128:765-770

Miller AE, Bowman WD (2003) Alpine plants show species-level differences in the uptake of organic and inorganic nitrogen. Plant Soil 250:283-292

Miller AE, Bowman WD, Suding KN (2007) Plant uptake of inorganic and organic nitrogen: neighbor identity matters. Ecology 88:18321840

Miller AE, Schimel JP, Sickman JO, Skeen KM, Melack T, Met J (2009) Seasonal variation in nitrogen uptake and turnover in two highelevation soils: mineralization responses are site-dependent. Biogeochemistry 93:253-270

Nacry P, Bouguyon E, Gojon A (2013) Nitrogen acquisition by roots: physiological and developmental mechanisms ensuring plant adaptation to a fluctuating resource. Plant Soil 370:1-29

Nasholm T, Sandberg G, Ericsson A (1987) Quantitative-analysis of amino-acids in conifer tissues by high-performance liquid-chromatography and fluorescence detection of their 9-fluorenylmethyl chloroformate derivatives. J Chromatogr 396:225-236
Näsholm T, Kielland K, Ganeteg U (2009) Uptake of organic nitrogen by plants. New Phytol 182:31-48

Nelson D, Sommers L (1982) Dry combustion method using medium temperature resistance furnace. In: Page AL, Miller RH, Keeney DR (eds) Methods of soil analysis. Part 2. Chemical and microbial properties, 2nd edn. Soil Science Society of America and American Society of Agronomy Book Series no. 9, Madison, pp 539-579

Olofsson J, Kitti H, Rautiainen P, Stark S, Oksanen L (2001) Effects of summer grazing by reindeer on composition of vegetation, productivity and nitrogen cycling. Ecography 24:13-24

Pathan S, Ceccherini M, Hansen M, Giagnoni L, Ascher J, Arenella M, Sørensen S, Pietramellara G, Nannipieri P, Renella G (2015a) Maize lines with different nitrogen use efficiency select bacterial communities with different $\beta$-glucosidase-encoding genes and glucosidase activity in the rhizosphere. Biol Fertil Soils. doi:10.1007\% 2Fs00374-015-1045-9

Pathan SI, Ceccherini MT, Pietramellara G, Puschenreiter M, Giagnoni L, Arenella M, Varanini Z, Nannpieri P, Renella G (2015b) Enzyme activity and microbial community structure in the rhizosphere of two maize lines differing in N use efficiency. Plant Soil 387:413-424

Piao S, Fang J, He J (2006) Variations in Vegetation Net Primary Production in the Qinghai-Xizang Plateau, China, from 1982 to 1999. Clim Chang 74:253-267

Rui YC, Wang SP, Xu ZH, Wang YF, Chen CR, Zhou XQ, Kang XM, Lu SB, Hu YG, Lin QY, Luo CY (2011) Warming and grazing affect soil labile carbon and nitrogen pools differently in an alpine meadow of the Qinghai-Tibet Plateau in China. J Soil Sediment 11:903-914

Schimel JP, Bennett J (2004) Nitrogen mineralization: challenges of a changing paradigm. Ecology 85:591-602

Schmidt S, Stewart GR (1999) Glycine metabolism by plant roots and its occurrence in Australian plant communities. Aust J Plant Physiol 26:253-264

Shen M, Tang Y, Chen J, Zhu X, Zheng Y (2011) Influences of temperature and precipitation before the growing season on spring phenology in grasslands of the central and eastern Qinghai-Tibetan Plateau. Agr Forest Meteorol 151:1711-1722

Streeter TC, Bol R, Bardgett RD (2000) Amino acids as a nitrogen source in temperate upland grasslands: the use of dual labelled (C-13, N-15) glycine to test for direct uptake by dominant grasses. Rapid Commun Mass Sp 14:1351-1355

Unteregelsbacher S, Hafner S, Guggenberger G, Miehe G, Xu X, Liu J, Kuzyakov Y (2012) Response of long-, medium-and short-term processes of the carbon budget to overgrazing-induced crusts in the Tibetan Plateau. Biogeochemistry 111:187-201

Vinolas LC, Vallejo VR, Jones DL (2001) Control of amino acid mineralization and microbial metabolism by temperature. Soil Biol Biochem 33:1137-1140

Vitousek PM, Howarth RW (1991) Nitrogen limitation on land and in the sea: how can it occur? Biogeochemistry 13:87-115

Wang WY, Wang QJ, Wang HC (2006) The effect of land management on plant community composition, species diversity, and productivity of alpine Kobersia steppe meadow. Ecol Res 21:181-187

Wang SP, Duan JC, Xu GP, Wang YF, Zhang Z, Rui YC, Luo CY, Xu B, Zhu XX, Chang XF (2012) Effects of warming and grazing on soil $\mathrm{N}$ availability, species composition, and ANPP in an alpine meadow. Ecology 93:2365-2376

Wang YJ, Wei XY, Yang P (2005) Effects of over-grazing on vegetation degradation of Kobresia pygmaea meadow in Nagqu, Tibet. J Lanzhou Univ Nat Sci 41:32-38

Warren CR (2014) Organic N molecules in the soil solution: what is known, what is unknown and the path forwards. Plant Soil 375:1-19

Wiener G, Jianlin H, Ruijun L (2003) The yak. FAO Regional Office for Asia and the Pacific. pp 28-47

Xu XL, Hua OY, Cao GM, Pei ZY, Zhou CP (2004) Uptake of organic nitrogen by eight dominant plant species in Kobresia meadows. Nutr Cycl Agroecosys 69:5-10 
Xu XL, Ouyang H, Kuzyakov Y, Richter A, Wanek W (2006) Significance of organic nitrogen acquisition for dominant plant species in an alpine meadow on the Tibet plateau, China. Plant Soil 285: 221-231

Xu XL, Ouyang H, Cao GM, Richter A, Wanek W, Kuzyakov Y (2011a) Dominant plant species shift their nitrogen uptake patterns in response to nutrient enrichment caused by a fungal fairy in an alpine meadow. Plant Soil 341:495-504

Xu XL, Ouyang H, Richter A, Wanek W, Cao GM, Kuzyakov Y (2011b) Spatio-temporal variations determine plant-microbe competition for inorganic nitrogen in an alpine meadow. J Ecol 99:563-571
Yan L, Zhou GS, Zhang F (2013) Effects of different grazing intensities on grassland production in China: a meta-analysis. PLoS One 8, e81466

Yang HJ, Li Y, Wu MY, Zhang Z, Li LH, Wan SQ (2011) Plant community responses to nitrogen addition and increased precipitation: the importance of water availability and species traits. Glob Chang Biol 17:2936-2944

Zheng SX, Lan ZC, Li WH, Shao RX, Shan YM, Wan HW, Taube F, Bai YF (2011) Differential responses of plant functional trait to grazing between two contrasting dominant $\mathrm{C}_{3}$ and $\mathrm{C}_{4}$ species in a typical steppe of Inner Mongolia, China. Plant Soil 340:141-155

Zhou XM (2001) Alpine Kobresia meadows in China. Science Press, Beijing, pp 51-62 